\title{
REVIEW
}

\section{Sex Pheromones and Plasmid Transfer in Enterococcus faecalis}

\author{
Don B. Clewell aNd KeITH E. WEAVER
}

\begin{abstract}
Departments of Biologic/Materials Sciences and Microbiology/Immunology, Schools of Dentistry and Medicine, and The Dental Research Institute, The University of Michigan, Ann Arbor, Michigan 48109
\end{abstract}

Received January 13, 1989; revised April 3, 1989

\begin{abstract}
Plasmid-free Enterococcus faecalis excrete peptides (sex pheromones) which specifically induce a mating response in strains harboring certain conjugative plasmids. The response is characterized by the synthesis of a "fuzzy" surface material, visible by electron microscopy, which is believed to facilitate the aggregation of donors and recipients. Transconjugants which receive a specific plasmid shut down the production of endogenous pheromone; however, they continue to produce pheromones specific for donors harboring different classes of plasmids. In this review, we summarize what is known about the biochemistry and genetics of this phenomenon. Some emphasis is given to the hemolysin plasmid pAD1 and the regulation of its conjugal transfer. (c) 1989 Academic Press, Inc.
\end{abstract}

Conjugative plasmids have been identified in numerous gram-positive bacteria, and many exhibit interspecies or intergeneric transfer (Clewell, 1981). One particular class of plasmids commonly found in Enterococcus (formerly Streptococcus) faecalis is unique in that a mating response is triggered by recipientproduced sex pheromones (Dunny et al., 1978). The involvement of sex pheromones correlates well with the ability of plasmid DNA to transfer in broth matings; this contrasts with the case for many other gram-positive conjugative plasmids, including some in $E$. faecalis, which do not transfer in broth but exhibit broad host-range transfer in matings occurring on solid surfaces (filter matings). Pheromoneresponding plasmids, examples of which are listed in Table 1, are the subject of this review.

E. faecalis, a Lancefield group D enterococcus, is a common inhabitant of the human gut. Strains frequently harbor plasmids determining drug resistance, hemolysins, and/or bacteriocins and may represent a reservoir of genetic information available to other bacteria in the intestine. A significant percentage of $E$. faecalis strains are hemolytic, a property frequently associated with a specific plasmid (see Table 1). Such strains are common among clinical isolates associated with human parenteral infections (Ike et al., 1987), and there is evidence that the hemolysin contributes to virulence in a mouse model (Ike et al., 1984). One such hemolysin plasmid is pAD1 (Table 1). Plasmids closely related to PAD1 have been identified in hemolytic isolates from widely separated geographical areas (LeBlanc et al., 1983; Ike et al., 1987; Colmar and Horaud, 1987); and it has been reported (Colmar and Horaud, 1987) that E. faecalis hemolysin plasmids form a single incompatibility group (IncHly). Most hemolytic isolates exhibit a similar pheromone-inducible mating response (Ike and Clewell, 1987). The pAD1 hemolysin plasmid will be referred to extensively in this review.

\section{NATURE OF THE AGGREGATION EVENT}

The pheromone response by donor cells requires about 30 to $40 \mathrm{~min}$ and is characterized by the synthesis of a proteinaceous substance that appears on the cell surface (Yagi et al., 1983) and facilitates the formation of mating aggregates upon random collision with recipient bacteria. Induced surface material, collectively referred to as aggregation substance (AS), ${ }^{1}$ appears as a fuzzy microfibrillar mate-

\footnotetext{
${ }^{1}$ Abbreviations used: AC, aggregation substance; BS, binding substance; LTA, lipoteichoic acid.
} 
TABLE 1

Plasmids Known to EnCode a Pheromone Response

\begin{tabular}{|c|c|c|c|c|c|}
\hline Plasmid & $\begin{array}{l}\text { Size } \\
(\mathrm{kb})\end{array}$ & $\begin{array}{l}\text { Original } \\
\text { host }\end{array}$ & Phenotype encoded ${ }^{a}$ & $\begin{array}{c}\text { Related } \\
\text { pheromone }\end{array}$ & Related reference(s) \\
\hline pAD1 & 60 & DS16 & Hly/Bac, uv & cAD1 & $\begin{array}{l}\text { Tomich et al., 1979; Clewell et al., } \\
\text { 1982a; Dunny et al., } 1979\end{array}$ \\
\hline pPD1 & 56 & $39-5$ & $\mathrm{Bac}$ & $\mathrm{cPD} 1$ & Yagi et al., 1983; Dunny et al., 1978 \\
\hline pAM373 & 36 & $\mathrm{RC73}$ & $?$ & cAM373 & Clcwell et al., 1985 \\
\hline pCF10 & 54 & $\mathrm{SF}-7$ & $\operatorname{Tc}^{\mathrm{T}}(\operatorname{Tn} 925)$ & cCF10 & Dunny et al., 1981 \\
\hline $\mathrm{pAM} \gamma \mathbf{1}$ & 60 & DS5 & Hly/Bac, uv & cAD1 & Clewell et al., 1982b \\
\hline $\mathrm{pAM} \gamma 2$ & $\sim 60$ & DS5 & $\mathrm{Bac}$ & $\mathrm{cAM}_{\gamma} 2$ & Clewell et al., 1982b \\
\hline $\mathrm{pAM} \gamma 3$ & $\sim 60$ & DS5 & $?$ & $\mathrm{cAM} \gamma 3$ & Clewell et al., 1982b \\
\hline pOB1 & 71 & 5952 & Hly/Bac & $\mathrm{cOB} 1$ & $\begin{array}{l}\text { Oliver et al., 1977; Clewell 1981; } \\
\text { unpublished data }\end{array}$ \\
\hline $\mathrm{pJH} 2$ & 59 & JH1 & Hly/Bac & cAD1 & $\begin{array}{l}\text { Jacob et al., 1975; Clewell 1981; } \\
\text { unpublished data }\end{array}$ \\
\hline pBEM10 & 70 & $\mathrm{HH} 22$ & $\operatorname{Pen}^{\mathrm{r}}, \mathrm{Gm}^{\mathrm{r}}, \mathrm{Km}^{\mathrm{r}}, \mathrm{Tm}^{\mathrm{r}}$ & $\mathrm{cAD} 1$ & Murray et al., 1988 \\
\hline pAM323 & 66 & $\mathrm{HH} 22$ & $\mathrm{Em}^{\mathrm{r}}$ & cAM323 & Murray et al., 1988 \\
\hline pAM324 & 53 & $\mathrm{HH} 22$ & $?$ & cAM324 & Murray et al., 1988 \\
\hline
\end{tabular}

${ }^{a}$ Hly, hemolysin; Bac, bacteriocin; uv, ultraviolet light resistance; $\mathrm{Tc}^{\mathrm{r}}$, tetracycline resistance; Pen $^{\mathrm{r}}$, penicillin resistance; $\mathrm{Gm}^{\mathrm{r}}$, gentamicin resistance; $\mathrm{Km}^{\mathrm{r}}$, kanamycin resistance; $\mathrm{Tm}^{\mathrm{r}}$, tobramycin resistance; $\mathrm{Em}^{\mathrm{r}}$, erythromycin resistance.

rial by immunoelectron microscopy (Yagi et al., 1983; Galli et al., 1989; Wanner et al., 1989) and several immunologically unique proteins ranging in size from about 73,000 to 157,000 Da have been detected on induced cells (Kessler and Yagi, 1983; Tortorello and Dunny, 1985; Ehrenfeld et al., 1986; Tortorello et al., 1986). Aggregation of donors and recipients is believed to involve a "binding substance" (BS) which is present on the recipient surface and to which AS binds (Dunny et al., 1979). Since donors alone will undergo an aggregation (clumping) response if exposed to the recipient pheromone, BS is believed to occur on the donor surface also. Aggregation requires phosphate ions and divalent cations (e.g., $\mathrm{Mg}^{2+}$ ) (Yagi et al., 1983). Lipoteichoic acid (LTA) may represent a component of BS because low concentrations $(0.1$ to $1.0 \mu \mathrm{g} / \mathrm{ml})$ of added LTA are able to inhibit the aggregation (Ehrenfeld et al., 1986). It is noteworthy in this regard that LTA corresponds to the Lancefield group D antigen on the E. faecalis surface (Wicken et al., 1963).

Wirth and colleagues (Galli et al., 1989; Wanner et al., 1989) isolated a pAD1-related 78-kDa surface protein and raised polyclonal rabbit antibodies against it. Using direct immunogold labeling they were able to observe a dense layer of "hairs" on the surface of induced donor cells. Interestingly, the hairs were not evenly distributed. It appeared that the fibrils established only on the cell wall that was present at the moment induction began. That is, the new wall made during the $30-40 \mathrm{~min}$ required for full induction may not give rise to AS. Such a behavior suggests a convenient way for donor cells to dissociate from mating aggregates after plasmid transfer (i.e., cell division would quickly give rise to donors free of AS).

Suzuki and colleagues (personal communication) have also purified and characterized the major inducible pAD1-related surface protein as well as the major inducible protein of pPD1 (see Table 1). Antiserum raised against the latter specifically was able to prevent aggregation of induced pPD1-containing cells. Amino-terminal analyses of both proteins showed significant differences in amino acid sequence, a result consistent with their immunological dissimilarity.

\section{MULTIPLE SEX PHEROMONES AND PHEROMONE INHIBITORS}

A plasmid-free strain of $E$. faecalis (e.g., FA2-2 or OG1X) excretes multiple peptide pheromones (Dunny et al., 1979; Clewell et 
al., 1982b), specific for different conjugative plasmids. When a specific plasmid such as pAD1 is acquired by a recipient cell, it shuts down the production of the related endogenous pheromone cAD1. However, the cell continues to excrete unrelated pheromones specific for other plasmids. At least five different pheromones are known to be produced by a single cell, and it is believed that the production of many more are likely. Not surprisingly, $E$. faecalis strains may carry more than one pheromone-responding plasmid; strains DS5 (Clewell et al., 1982b) and HH22 (Murray et al., 1988) each carry three such plasmids (Table 1).

Plasmid-containing cells excrete a unique peptide that behaves as a competitive inhibitor (e.g., iAD1) of the pheromone to which the cells respond (Ike et al., 1983). The inhibitor may serve to prevent induction by low levels of endogenous pheromone or by different pheromones with low levels of cross-reacting activity for the plasmid-specific pheromone receptor site. It may also act to prevent induction by pheromone levels too low to result in the generation of mating aggregates (i.e., recipients being too far away to encounter by random collision). There is evidence supporting the view that the inhibitor $\mathrm{ADD} 1$ is encoded by the plasmid pAD1. Specifically, when the plasmid was introduced into a strain which did not exhibit a cAD1 pheromone system (e.g., E. faecium 9790), iAD1 was excreted (Clewell et al., 1987).

Several pheromones and some of the related inhibitor peptides have been purified and characterized by Suzuki and collaborators; their structures are shown in Table 2. All are hydrophobic octa- or heptapeptides. The pheromones have at least one hydroxyamino acid residue, which possibly could serve as a modification site for the shutdown (inactivation) of endogenous pheromone activity when the corresponding plasmid is present. A derivative of $\mathrm{pAD} 1$ with a $2.5-\mathrm{kb}$ deletion has recently been found unable to shut down endogenous cAD1 production (Weaver and Clewell, 1988; see below); the specific shutdown mechanism remains to be determined. cAD1 and iAD1 are 50\% homologous, with four of eight amino acid residues being identical (Table 2). cPD1 and iPD1 are only $25 \%$ homologous; however, iPD1 and i $\Lambda$ D1 have three adjacent residues in common. It is noteworthy that the heptapeptide $\mathrm{CCF} 10$ has four adjacent residues in common with iAD1.

Synthetic sex pheromone and inhibitor peptides were found to have full activity and exhibited strong specificity for the related plasmid system. Deletion of one amino acid from the amino-terminus reduced cPD1 activity to $0.5 \%$, and further deletions from this end resulted in essentially complete inactivation (Kitada et al., 1985). Deletion of the carboxy-terminal residue of $\mathrm{CPD} 1$ diminished activity completely. In the case of $\mathrm{CAD} 1$, deletion of the amino-terminal residue resulted in no detectable activity, whereas deletion of the carboxy-terminal residue reduced activity to $0.02 \%$ (Kitada et al., 1985). The full lengths of $\mathrm{cPD} 1$ and $\mathrm{CADl}$, therefore, are important to CIA activity.

Synthetic hybrid peptides corresponding to cPD1 on the amino-terminal half and cAD1

TABLE 2

Structures of SeX PHeromones and SOME Related INHIBITORS

\begin{tabular}{lrl}
$\begin{array}{l}\text { Pheromone or } \\
\text { inhibitor }\left(M_{\mathrm{r}}\right)\end{array}$ & Peptide structure & Reference \\
\hline cPD1 (912) & H-Phe-Leu-Val-Met-Phe-Leu-Ser-Gly-OH & Suzuki et al., 1984 \\
cAD1 (818) & H-Leu-Phe-Ser-Leu-Val-Leu-Ala-Gly-OH & Mori et al., 1984 \\
cAM373(733) & H-Ala-Ile-Phe-Ile-Leu-Ala-Ser-OH & Mori et al., 1986b \\
cCF10 (789) & H-Leu-Val-Thr-Leu-Val-Phe-Val-OH & Mori et al., 1988 \\
iPD1 (828) & H-Ala-Leu-Ile-Leu-Thr-Leu-Val-Ser-OH & Mori et al., 1987 \\
iAD1 (846) & H-Leu-Phe-Val-Val-Thr-Leu-Val-Gly-OH & Mori et al., 1986a \\
\hline
\end{tabular}


on the carboxy-terminal half exhibited $10 \%$ the activity of cPD1 but had no cADI activity (Kitada et al., 1985). The converse structure gave the opposite result, with $1 \%$ the activity of cAD1 and no cPD1 activity. Thus, the specificity of the peptide is determined by the amino-terminal sequences.

\section{PLASMID TRANSFER}

When donors are exposed to pheromone for $60 \mathrm{~min}$ and then mated with recipients for a short period of time ( 10 to $15 \mathrm{~min}$ ), the frequency of transfer is generally 3 to 6 orders of magnitude greater than controls not previously induced. Transfer can occur readily between two homolgous donor strains if one of them is induced prior to the brief mating (Clewell and Brown, 1980). In such experiments where the two donors each had a distinguishable derivative of $\mathrm{pAD} 1$ (i.e., using the tetracyclineresistance transposon $\operatorname{Tn} 916$ or the erythromycin resistance transposon $\operatorname{Tn} 917)$ significant transfer occurred only in the direction from induced to uninduced cells. It was concluded from such experiments that in addition to inducing AS, genes necessary for DNA transfer were also induced. Had the induction of aggregation-related surface material been the only important pheromone-related response, one would have expected transfer in both directions between the two donors, regardless of which had been induced prior to the mating. Interestingly, when both donors were induced transfer occurred in both directions but at frequencies significantly reduced from the case where transfer was from an induced to an uninduced strain. Thus, entry (surface) exclusion also appears to be induced by pheromone. In the case of pCF10 Dunny et al. (1985) have reported evidence that a 130$\mathrm{kDa}$ surface protein induced by pheromone (cCF10) is involved in surface exclusion. It was also shown that exclusion was specific in that entrance of pAD1 was not affected. A pheromone-induced surface exclusion would seem important in order to minimize exchange of plasmid DNA between homologous donors that are in close proximity to one another, along with recipients, in mating aggregates.
Consistent with the finding that genes other than those related to aggregation are also induced by pheromone is the observation that a bacterial strain harboring derivatives of both pPD1 and pAD1 is specific in its pheromone response (Ehrenfeld et al., 1986). That is, when the cells were exposed to only cPD1 prior to a short mating, only the pPD1 derivative (marked with Tn916) transferred. On the other hand when the cells were induced with cAD 1 only the pADI derivative (marked with Tn917) was found to transfer. These data implicate independent signal transduction pathways and are consistent with an absence of trans-complementation between unrelated, coresident, pheromone-responding plasmids.

\section{INDUCIBLE CELL SURFACE PROTEINS}

The pAD1 pheromone response involves the sythesis of at least four novel surface proteins that are readily detectable after 45 to 60 min (Ehrenfeld et al., 1986). Using antiserum raised in rabbits against induced bacteria, proteins with $M_{\mathrm{r}}$ values of approximately 74,000 , $130,000,153,000$, and 157,000 (referred to as AD74, AD130, AD153, and AD157, respectively) are observed. $\mathrm{AD} 130, \mathrm{AD} 153$, and AD157 strongly cross-reacted with similar bands that relate to the induction of pPD 1 (PD130, PD153, and PD157). AD74 was the most prominant band produced and could be detected on gels stained with Coomassie blue. This band probably corresponds to a similar band (designated PD78) produced by pPD1containing cells. AD74 and PD78 are immunologically distinct and represent the two major AS proteins that have been purified and characterized (see above). Similarly, Tortorello and Dunny (1985) detected several inducible surface antigens in the pCF 10 system; these exhibited $M r$ values of 73,000 to 130,000 . The smaller protein, designated SA73, was the most prevalent and may be analogous to $\mathrm{AD} 74$ and PD78.

\section{GENETIC ANALYSIS OF pAD1}

The transposon Tn917 (Tomich et al., 1980) has been useful in genetic analyses of 
the pheromone-responding plasmids pAD1 and pCF10. In particular the construction by Youngman (1987) and colleagues of useful derivatives along with temperature-sensitive plasmid delivery vectors has been valuable (Weaver and Clewell, 1987). For both pAD1 and $\mathrm{pCF} 10$, inserts over large regions of the plasmid have been observed to affect mating. As shown in Fig. 1, insertions in pAD1 over a segment representing well over half of the plasmid exhibited significant effects on transferability (Ehrenfeld and Clewell, 1987). Insertions in regions $\mathrm{D}, \mathrm{E}, \mathrm{F}, \mathrm{G}$, and $\mathrm{H}$ greatly reduced or eliminated the ability of pAD1 to transfer in broth. Insertions in region $\mathrm{H}$ allowed cells to still undergo inducible aggregation, but plasmid transfer was not detectable in broth and was less than $0.7 \%$ of the wild-

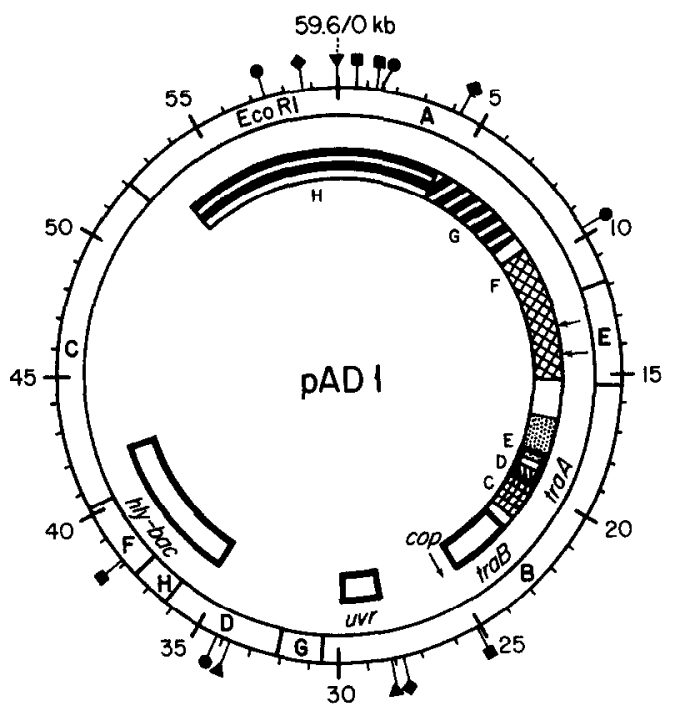

FIG. 1. Physical and functional map of pAD1. Regions important for transfer are indicated as shaded or open boxes on the interior of the map and labeled $\operatorname{tr} a A, \operatorname{traB}$, and $\mathrm{C}$ through $\mathrm{H}$. Regions $h l y-b a c$ and $u v r$ represent genes for hemolysin-bacteriocin and uv resistance, respectively. EcoRI fragments are labeled within the outer circle. Other restriction sites are SalI, $\mathbf{\nabla} ; B a m H I, \mathbf{v} ; K p n I$, ; and $P s t I$, - This figure is identical to that shown in Ehrenfeld and Clewell (1987) with the following exceptions: (i) the F region has been extended to include a number of inserts in the EcoRI E fragment which resulted in altered surface protein production; and (ii) the $E$ region has been extended to include an insert (NR5) with a characteristic phenotype. type in filter matings. Aggregation also was not affected by insertions in the adjacent $G$ region; transfer, however, occurred at about $5 \%$ of wild-type levels in broth. All four of the inducible surface proteins could be detected for both $\mathrm{G}$ and $\mathrm{H}$ insertions. These two regions probably include determinants necessary for DNA transfer. Region $F$ insertion derivatives did not undergo induced aggregation and/or were altered in the appearance of inducible surface proteins. In several cases both AD74 and AD157 were missing, but AD130 and AD153 appeared normal; in addition, a 140$\mathrm{kDa}$ protein was readily evident. The latter may represent an increased level of an "AD140" barely detectable in the case of induced wild-type cells. One insert in region F exhibited only AD74 and a "new" 110-kDa protein. F-region mutants exhibited a reduced transfer (about $4 \%$ of wild-type) in broth, but wild-type transfer on filters, indicating that the ability to transfer DNA was not affected. The two inserts indicated by the arrows in Fig. 1 did not prevent induced aggregation. One insert (at $12.8 \mathrm{~kb}$ ) resulted in undetectable levels of transfer in broth, but transfer occurred at wild-type levels in filter matings. This derivative produced only the AD153 surface protein. In another case (at $14.1 \mathrm{~kb}$ ), transfer in broth occurred normally, despite the induction of only AD74 and AD153. Although it would appear that cells producing only AD153 are able to form aggregates in broth, the role (if any) of this protein in aggregation is more complex; region $F$ insertions, which produced AD153 (or a similar-sized protein) along with $\mathrm{AD} 130$ and $\mathrm{AD} 140$, did not give rise to visible aggregates. It is not clear why certain variants not exhibiting AD74 (the presumed major AS component [see above]) still appear able to aggregate. Conceivably these cells have low, difficult-to-detect, levels of AD74 or have an unextractable, perhaps precursor, form of the protein. More work will be required to gain insight into the specific role played by the various surface proteins.

The remaining regions, located further clockwisc, constitute a 7-kb segment involved in the regulation of the pheromone response. 
It has been proposed that two products, determined by traA and $t \mathrm{raB}$ (Figs. 1 and 2), act in concert to negatively control the pheromone rcsponse (Ike and Clewell, 1984; Ehrenfeld and Clewell, 1987; Weaver and Clewell, 1988). Tn917 inserts within either of these regions resulted in constitutive expression of the inducible surface proteins and cell aggregation in the absence of pheromone. Such strains also exhibit a high level of plasmid transfer in short ( $10 \mathrm{~min}$ ) broth matings. These characteristics typify those of cells containing wild-type pADI after exposure to cAD1. Wild-type pAD1containing cells give rise to "dry" colonies when grown on plates containing pheromone. However, traA mutants form dry colonies in the absence of pheromone. Colonies of $\operatorname{tra} B$ mutants exhibit a "ringed" colony morphology with a dry center and become uniformly dry upon exposure to pheromone (Weaver and Clewell, 1988). The ringed colony morphology was observed in E. faecalis strain OG1X, but not in the unrelated host, FA2-2, where colonies appeared normal (as if uninduced) in the absence of pheromone (Ike and Clewell, 1984). Constitutive aggregation was also observed in a subset of $\operatorname{Tn} 917$ insertions within the $\mathrm{C}$ region (Fig. 2). Colonies of these mutants produced a semidry colony morphology in OG1X more closely resembling that of $\operatorname{traA}$ derivatives. Plasmid DNA transferred constitutively, but the cells produced detectably elevated amounts of only one surface protein, AD74, in the absence of pheromone. C-region mutants could be further induced, with respect to production of surface proteins, by addition of pheromone (Weaver and Clewell, 1988). Interestingly, the $\mathrm{A} 3$ deletion (Fig. 2) allows production of pheromone and removes a portion of the $\operatorname{tr} a B$ gene and nearly all of the $C$ region, yet no single insert in either region interferes with pheromone "shutdown." This suggests that two or more gene products may cooperate to shut down pheromone production.

The product of the traA gene may also be involved in transduction of the pheromone induction signal. Western blot analyses revealed that, while traA mutants produced all of the normally inducible surface proteins constitutively, they were produced at levels lower (10-50\% depending on whether FA2-2 or OG1X was used as a host) than observed in induced cells containing the wild-type plas-

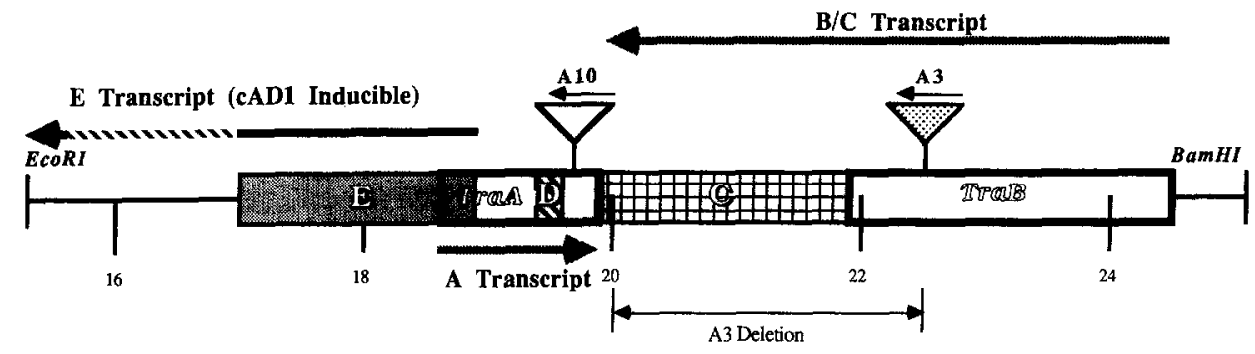

FIG. 2. Transcriptional map of the pAD1 pheromone-response control region. Direction and extent of transcripts were determined on the basis of pheotypes of a number of Tn917 (Ike and Clewell, 1984; Ehrenfeld and Clewell, 1987) and Tn917lac (Weaver and Clewell, 1988) inserts and the transcription properties of lac $Z$ transcriptional fusions within each region. The stipled arrows indicate the low-level constitutive expression of lac $Z$ fusions in the $\operatorname{traA}, \operatorname{tr} a B$, and $\mathrm{C}$ regions compared to the high-level pheromone inducible production of $\beta$-galactosidase from E-region fusions. The cross-hatching of the E-region transcript represents uncertainty as to the terminus of this transcript. It should be noted that the transcripts indicated represent a minimum number of transcripts based on similar transcription properties of groups of fusions. It is certainly possible that one or all of the transcripts shown will be further subdivided as more information becomes available. Insert A10 and the A3 deletion are included for reference. This figure is similar to Fig. 2 of Weaver and Clewell (1988) except that the E region has been extended (see legend to Fig. 1) and the previously mapped $\mathrm{D}$ region is included for reference. In addition, it was found that the orientation of the $\mathrm{A} 3$ deletion with respect to the plasmid $E c o$ RI and BamHII sites was crroncously assigned (K. Weaver, unpublished results). The orientation and position of the deletion are corrected here. 
mid (Weaver and Clewell, 1988; and unpublished data). The levels of these proteins in $\operatorname{tra} A$ mutants could not be increased by the addition of pheromone, indicating that their expression was insensitive to the pheromone. In addition, several $\operatorname{Tn} 917$ inserts in $\operatorname{tr} A A$ have been isolated which constitutively expressed surface proteins at a lower level than other traA mutants, making their failure to respond to pheromone more apparent. For example, mutants A10 (Fig. 2) and pAM727 and pAM728 (Tn917 insertions in traA; Ike and Clewell, 1984) aggregated constitutively in OG1X but failed to aggregate in FA2-2 in the presence or absence of pheromone. In addition, A10 produced significantly decreased amounts of the inducible surface proteins in OG1X when compared to other traA mutants and undetectable amounts in FA2-2. In neither case could the amount of inducible surface proteins be increased by exposure to pheromone. Similarly, pAM727 and pAM728 showed a constitutive, but low-level transfer of plasmid DNA from a FA2-2 donor that could not be increased by the addition of pheromone. It is possible that these independently isolated mutants define the same phenotype; both were partially derepressed in the absence of pheromone, but did not respond to the presence of pheromone. Three other mutants have also been isolated near or within tra $A$ in a region designated $\mathrm{D}$ (Ehrenfeld and Clewell, 1987). Two of these three inserts failed to aggregate in response to pheromone while the third was capable of aggregation, but none of the three were capable of plasmid transfer in liquid media. Further investigation of these mutants may help to determine the rolc of the traA product in pheromone signal sensing.

E-region inserts block all aspects of the pheromone response, as derivatives failed to aggregate, produce surface proteins, or transfer plasmid DNA--even in filter matings (Ehrenfeld and Clewell, 1987). LacZ transcriptional fusions within the $\mathrm{E}$ region, generated using Tn917lac (Youngman, 1987), were shown to be inducible, clearly indicating that the E-region product(s) is not necessary for pheromone sensing (Weaver and Clewell, 1988). Thus, the related determinant(s) may include a positive regulator necessary for expression of products (e.g., in regions $F, G$, and $H$ ) needed for aggregation and DNA transfer. The $E$ region may also contain the beginning of an operon running counterclockwise. It is evident that there must be several promoters in the large segment that include $F, G$, and $H$, since insertions there do not necessarily have a polar effect on expression. For example, insertions in the $F$ region, which interfere with the aggregation response, do not seem to affect transfer functions encoded in the $\mathrm{H}$ region.

Analyses of fusions within the regulatory region revealed at least three transcripts on the basis of transcriptional dircction and $\beta$-galactosidase production (Weaver and Clewell, 1988; Fig. 2). The E transcript is transcribed in a leftward or counterclockwise direction, and fusions within this region are inducible, as noted above. The $C /$ traB and $t r a A$ transcripts are produced constitutively at equivalent levels but are transcribed in opposite directions.

\section{ANALYSIS OF pCF10}

Transposon mutagenesis has also been used to determine the organization of pheromone response-related genes in pCF 10 (Christie and Dunny, 1986). In this plasmid a central region has been identified and appears to produce two separate products, encoded within regions designated R 130 and R150, which function as positive regulators of two different pheromone-inducible surface antigens, one involved in surface exclusion, Tra130, and the other in aggregation, Tra150. The structural genes for these surface antigens are located to one side of the putative positive regulators (Christie $e t$ al., 1988). On the opposite side of R130 and $\mathrm{R} 150$, is a region, designated tra1-tra2-tra3, within which at least one negatively regulating product is determined. In addition, inserts in the different negative regulatory loci resulted in qualitatively different constitutive aggregation characteristics (Christie and Dunny, 1986). This arrangement is similar to the organization of pAD1, in which the negative 
regulatory genes, $\operatorname{tr} a A$ and $\operatorname{tr} a B$, and genes which affect the production of various surface proteins (the $F$ region) are located on opposite sides of a putative positive regulatory region (the $\mathrm{E}$ region). Some differences in gene arrangement are apparent between the two plasmids, however. For instance, with the possible exception of a single locus identified by three Tn917 inserts, no region of pCF 10 has yet been identified which is absolutely required for induction of all aspects of the pheromone response. In addition, inserts in several regions on the opposite side of R130 and R150 from tra1-tra2-tra3 have been isolated which resulted in constitutive aggregation (Christie and Dunny, 1986). It will be interesting to compare the genetic organization of $\mathrm{pAD} 1$ and $\mathrm{pCF} 1$ as work progresses.

\section{CONCLUDING REMARKS}

The fact that plasmid-free strains of $E$. faecalis excrete multiple peptides which serve as mating signals relating to a variety of plasmids perhaps never previously encountered suggests that production of these substances may have preceded the evolution of the related conjugative systems. The plasmid systems may have evolved in such a way as to take advantage of these extracellular compounds as mating signals. The question then arises as to the nature of the original, and perhaps continuing, function of these peptides. In this regard, it is interesting that an activity similar to that of the pheromone cAM373 (Clewell et al., 1985) is also produced by essentially all strains of coagulase positive staphyococci (i.e., Staphylococcus aureus), but not by coagulase negative staphylococci (e.g., S. epidermidis); the activity is also produced by about $15 \%$ of Streptococcus sanguis strains. There is no evidence that such activities act as pheromones in these species.

It is surprising that in the 10 years since sex pheromone-induced plasmid transfer was discovered in E. faecalis, such mating signals have still not been identified in other species of bacteria. The closest thing to sex pheromones may be the competence factors associated with transformation phenomena of Streptococcus pneumoniae and Streptococcus sanguis (To- masz, 1969; Lacks, 1977). These extracellular substances seem to facilitate a synchronous appearance of the competent state of a given culture. However, in nature it is conccivablc that transformational recombination between different strains could be influenced by these compounds. In such cases these factors might, in a sense, be viewed as sex pheromones.

\section{ACKNOWLEDGMENTS}

We thank our colleagues who supplied us with reprints or preprints of their work, especially G. Dunny, R. Wirth, and A. Suzuki. We also thank Linda Pontius and Hlorence An for helpful discussions. Work from our laboratory described in this review was supported by USPHS Grants GM33956, AI10318, and DE02731.

\section{REFERENCES}

Christie, P. J., AND DUNNY, G. M. (1986). Identification of regions of the Streptococcus faecalis plasmid pCF-10 that encode antibiotic resistance and pheromone response functions. Plasmid 15, 230-241.

Christie, P. J., KaO, M., Adsit, J. C., AND DunNY, G. M. (1988). Cloning and expression of genes encoding pheromone-inducible antigens of Enterncoccus (Streptococcus) faecalis. J. Bacteriol. 170, 5161-5168.

Clewell, D. B. (1981). Plasmids, drug resistance, and gene transfer in the genus Streptococcus. Microbiol. Rev. 45, 409-436.

Clewell, D. B., AN, F. Y., Mori, M., IKe, Y., AND SUZUKI, A. (1987). Streptococcus faecalis sex pheromone (cADI) response: Evidence that the peptide inhibitor excreted by pADl-containing cells may be plasmid determined. Plasmid 17, 65-68.

Clewell, D. B., AN, F. Y., White, B. A., And GawronBURKE, C. (1985). Streptococcus faecalis sex pheromone (cAM373) also produccd by Staphylococcus aureus and identification of a conjugative transposon (Tn918). $J$. Bacteriol. 162, 1212-1220.

Clewell, D. B., AND Brown, B. L. (1980). Sex pheromone cAD1 in Streptococcus faecalis: Induction of a function related to plasmid transfer. J. Bacteriol. 143, 1063-1065.

Clewell, D. B., Ehrenfeld, E. E., KEsSler, R. E., IKE, Y., Franke, A. E., Madion, M., Shaw, J. H., Wirth, R., AN, F., MORI, M., Kitada, C., Fujino, M., AND SuzUKI, A. (1986). Sex-pheromone systems in Streptococcus faecalis. In "Banbury Report 24: Antibiotic Resistance Genes: Ecology, Transfer and Expression," pp. 131-142. Cold Spring Harbor, Cold Spring Harbor, NY.

Clewell, D. B., TUmich, P. K., Gawron-Burke, M. C., Franke, A. E., YAGI, Y., AND AN, F. Y. (1982a). Mapping of Streptococcus faecalis plasmids pADl and 
pAD2 and studies relating to transposition of $\operatorname{Tn} 917$. J. Bacteriol. 152, 1220-1230.

Clewell, D. B., Yagi, Y., IKe, Y., CRaIG, R. A., Brown, B. L., AND AN, F. (1982b). Sex pheromones in Streptococcus faecalis: Multiple pheromone systems in strain DS5, similarities of pAD1 and $\mathrm{pAM}_{\gamma} 1$, and mutants of pADl altered in conjugative properties. In "Microbiology-1982" (D. Schlessinger, Ed.), pp. 97-100. ASM, Washington, DC.

Colmar, I., AND Horaud, T. (1987). Enterococcus faecalis hemolysin-bacteriocin plasmids belong to the same incompatibility group. Appl. Environ. Microbiol. 53, $567-570$.

DunNy, G. M., Brown, B. L., AND Clewell, D. B. (1978). Induced cell aggregation and mating in Streptococcus faecalis: Evidence for a bacterial sex pheromone. Proc. Natl. Acad. Sci. USA 75, 3470-3483.

Dunny, G. M., Craig, R. A., Carron, R. L., AND ClfwFll, D. B. (1979). Plasmid transfer in Streptococcus faecalis: Production of multiple sex pheromones by recipients. Plasmid 2, 454-465.

DunNy, G., Funk, C., AND ADSIT, J. (1981). Direct stimulation of the transfer of antibiotic resistance by sex pheromones in Streptococcus faecalis. Plasmid 6, 270278.

DUNNy, G. M., Zimmerman, D. L., AND TORTOREllo, M. L. (1985). Induction of surface exclusion (entry exclusion) by Streptococcus faecalis sex pheromones: Use of monoclonal antibodies to identify an inducible surface antigen involved in the exclusion process. Proc. Natl. Acad. Sci. USA 82, 8582-8586.

EHRenFeld, E. E., AND Clewell, D. B. (1987). Transfer functions of the Streptococcus faecalis plasmid pADI: Organization of plasmid DNA encoding response to sex pheromone. J. Bacteriol. 169, 3473-3481.

Ehrenfeld, E. E., Kessler, R. E., AND Clewell, D. B. (1986). Identification of pheromone-induced surface proteins in Streptococcus faecalis and evidence of a role for lipoteichoic acid in formation of mating aggregates. J. Bacteriol. 168, 6-12.

GALli, D., WIRTH, R., AND WANNER, G. (1989). Identification of aggregation substances of Enterococcus fae. calis cells after induction by sex pheromones. Arch. Microbiol., in press.

IKE, Y., AND CLEWELL, D. B. (1984). Genetic analysis of the pADI pheromone response in Streptococcus faecalis, using transposon $\operatorname{Tn} 917$ as an insertional mutagen. $J$. Bacteriol. 158, 777-783.

IKE, Y., AND ClewELL, D. B. (1987). High incidence of hemolysin production by Streptococcus faecalis strains associated with human parenteral infections: Structure of hemolysin plasmids. In "Streptococcal Genetics" (J. Ferretti and R. Curtiss III, Eds.), pp. 159-164. ASM, Washington, DC.

IKe, Y., CRaIG, R. C., White, B. A., YAGI, Y., AND ClewEll, D. B. (1983). Modification of Streptococcus faecalis sex pheromones after acquisition of plasmid DNA. Proc. Natl. Acad. Sci. USA 80, 5369-5373.

IKE, Y., HaShimoto, H., AND Clewell, D. B. (1984). Hemolysin of Streptococcus faecalis subspecies zymo- genes contributes to virulence in mice. Infect. Immun. 45, 528-530.

IKE, Y., Hashimoto, H., AND Clewel, D. B. (1987). High incidence of hemolysin production by Enterococcus (Streptococcus) faecalis strains associated with human parenteral infections. J. Clin. Microbiol. 25, 1524 1528.

JACOB, A., DOUGlas, G. I., AND HobBS, S. J. (1975). Selftransferable plasmids determining the hemolysin and bacteriocin of Streptococcus faecalis var. zymogenes. $J$. Bacteriol. 121, 863-872.

KESSLER, R., AND YAGI, Y. (1983). Identification and partial characterization of a pheromone-induced adhesive surface antigen of Streptococcus faecalis. J. Bacteriol. 155, 714-721.

Kitada, C., Fujino, M., Mori, M., Sakagami, Y., Isogal, A., Suzukl, A., Clewell, D., and Craig, R. (1985). Synthesis and structure-activity relationships of Streptococcus faecalis sex pheromones, cPD1 and cAD1. In "Peptide Chemistry 1984" (N. Izumiya, Ed.), pp. 43-48. Protein Research Foundation, Osaka.

LACKS, S. (1977). Binding and entry of DNA in bacterial transformation. In "Microbial Interactions Series B. Receptors and Recognition" (J. L. Reissig, Ed.), Vol. 3, pp. 177-232. Chapman and Hall, London.

LeBlanc, D. J., Lee, L. N., Clewell, D. B., AND BEHNKE, D. (1983). Broad geographical distribution of a cytotoxin gene mediating beta-hemolysis and bacteriocin activity among Streptococcus faecalis strains. Infect. Immun. 40, 1015-1022.

Mori, M., Isogai, A., Sakagami, Y., Funjino, M., KITADA, C., Clewell, D. B., AND SuzuKi, A. (1986a). Isolation and structure of Streptococcus faecalis sex pheromone inhibitor, iAD1, that is excreted by donor strains harboring plasmid pAD1. Agric. Biol. Chem. 50, 539-541.

Mori, M., SaKagami, Y., IShII, Y., ISUGal, A., KITAda, C., FuJino, M., ADSIT, J. C., DUNNY, G. M., AND SUZUKI, A. (1988). Structure of CCF10, a peptide sex pheromone which induces conjugative transfer of the Streptococcus faecalis tetracycline-resistance plasmid, pCF 10 . J. Biol. Chem. 263, 14,574-14,578.

Mori, M., Sakagami, Y., Narita, M., IsOgal, A., Fujino, M., Kitada, C., CRaig, R., Clewell, D., AND SUZUKI, A. (1984). Isolation and structure of the bacterial sex pheromone, cAD1, that induces plasmid transfer in Streptococcus faecalis. FEBS Lett. 178, 97100.

Mori, M., Tanaka, H., Sakagami, Y., Isogai, A., FuGino, M., Kitada, C., Clewell, D. B., and Suzuki, A. (1987). Isolation and structure of the sex pheromone inhibitor, iPD1, excreted by Streptococcus faecalis donor strains harboring plasmid pPD1. J. Bacteriol. 169, 1747 1749.

Mori, M., Tanaka, H., Sakagami, Y., Isogai, A., FuJino, M., Kitada, C., White, B. A., AN, F. Y., CleWELL, D. B., AND SuzuKI, A. (1986b). Isolation and structure of the Streptococcus faecalis sex pheromone, cAM373. FEBS Lett. 206, 69-72.

Murray, B. E., AN, F., AND Clewell, D. B. (1988). 
Plasmids and pheromone response of the $\beta$-lactamasc producer Streptococcus (Enterococcus) faecalis $\mathrm{HH} 22$. Antimicrob. Agents Chemother. 32, 547-551.

OLIVER, D. R., BROWN, B. L., AND CLEWELL, D. B. (1977). Characterization of plasmids determining hemolysin and bacteriocin production in Streptococcus faecalis 5952. J. Bacteriol. 130, 948-950.

Suzuki, A., Mori, M., Sakagami, Y.. Isogal, A.. Fun: jino, M., Kitada, C., Craig. R. A.. and Cleweil., D. B. (1984). Isolation and structure of bacterial sex pheromone cPDI. Science 226, 849-850.

Tomasz, A. (1969). Some aspects of the competent state in genetic transformation. Annu. Rev. Genet. 3, $217-$ 232.

TOMiCh, P. K., AN, F. Y., AND CleWfll, D. B. (1980). Properties of erythromycin-inducible transposon $\operatorname{Tn} 917$ in Streptococcus faecalis. J. Bacteriol. 141, 1366-1374.

TOMICH, P. K., AN, F. Y., DAMLE, S. P.. AND CI.EWEll., D. B. (1979). Plasmid related transmissibility and multiple drug resistance in Streptococcus faecalis subspecies zymogenes strain DS16. Antimicrob. Agents Chemother. 15, 828-830.

Tortorello, M., Adsit, J., Krug, D., antczak, D., AND DUNNy, G. (1986). Monoclonal antibodies to cell surface antigens involved in sex pheromone induced mating in Streptococcus faecalis. J. Ge'n. Microbiol. 132, 857-864.

TORTORELlo, M. L., AND DLNNY, G. M. (1985). Identification of multiple surface antigens associated with the sex pheromone response of Sireptococtus factalis. J. Bacteriol. 162, 131-137.

WANNER, G.. Formanfe, H., GaLII, D., ANI) WIRTH, R. (1989). Location of aggregation substances of $F_{n}$ terococius faecalis after induction by sex pheromones. Arch. Microbiol., in press.

WFAVER, K. E.. AND CLIWFLL, D. B. (1987). Transposon Tn 917 delivery vectors for mutagenesis in Sireptococus faecalis. In "Streptococcal Genetics" (J. Ferretti and R. Curtiss III. Eds.). pp. 17-21. ASM, Washington, DC.

WEAVFR, K. F., AND CLFWELL., D. B. (1988). Regulation of the pADI sex pheromone response in Enterococcus faecalis: Construction and characterization of $l a c Z$ transcriptional fusions in a key control region of the plasmid. J. Bacteriol. 170, 4343-4352.

WiCKF, A. J., Elliott. S. D., AND BADDILEY. J. (1963). The identity of streptococcal group $D$ antigen with teichoic acid. J. Gien. Microbiol. 31, 231-239.

YaGi, Y.. Kessller, R. E.. Shaw. J. H., Lopativ, D. E., AN, F. Y., AND C1.EWELI., D. B. (1983). Plasmid content of Streptococcus faecalis strain $39-5$ and identification of a pheromone ( $C$ PD1)-induced surface antigen. $J$. Gen Microbiol. 129, 1207-1215.

Youngman, P. J. (1987). Plasmid vectors for recovering and exploiting $\operatorname{Tn} 9 / 7$ transposition in Bacillus and other gram-positives. In "Plasmids: A Practical Approach" (K. Hardy. Fd.), pp. 79-103. IRL Press, Oxford.

Communicated by Francis L. Macrina 